\title{
Procedury pomiarów parametrów optycznych endoskopów stosowanych w zabiegach diagnostyczno-leczniczych
}

\section{Measurement procedures of optical parameters of endoscopes applied to treatment and diagnosing processes}

\author{
Jacek Galas ${ }^{1}$, Adam Czyżewski ${ }^{1}$, Dariusz Litwin ${ }^{1}$, Piotr Janeczek², Witold Cieśla² \\ ${ }^{1}$ Instytut Optyki Stosowanej im. prof. Maksymiliana Pluty, Zakład Optyki Fizycznej, Warszawa \\ ${ }^{2}$ Instytut Fizjologii i Patologii Słuchu, Światowe Centrum Słuchu, Warszawa/Kajetany
}

Adres autora: Jacek Galas, Instytut Optyki Stosowanej im. prof. Maksymiliana Pluty, ul. Kamionkowska 18, 03-805 Warszawa, e-mail: galasj@inos.pl

\section{Streszczenie}

W artykule przedstawione zostały procedury pomiarowe wybranych parametrów optycznych endoskopów wykorzystywanych w zabiegach diagnostyczno-leczniczych. Procedury te zostały opracowane przez Instytut Fizjologii i Patologii Słuchu (IFPS) oraz Instytut Optyki Stosowanej (INOS) na podstawie doświadczeń medycznych oraz wiedzy z zakresu optyki instrumentalnej. Badane były między innymi: równomierność oświetlenia obiektu przez układ optyczny endoskopu oraz jego wpływ na rejestrowany obraz, rozdzielczość rejestrowanego obrazu, wartość transmisji układu oświetlającego i rejestrującego, głębia ostrości oraz dystorsja układu. Parametry te mają znaczący wpływ na jakość odwzorowania obrazu, a tym samym na ocenę przez lekarza zmian chorobowych u pacjenta.

Słowa kluczowe: urządzenia optyczne • obrazowanie optyczne • raport techniczny

\section{Abstract}

The paper demonstrates a collection of measurement testing processes of selected optical parameters of endoscopes applied to treatment and diagnosing procedures. They have been developed by two research centers: the Institute of Physiology and Pathology of Hearing (IFPS) and the Institute of Applied Optics (INOS). In order to accomplish this work the two Institutes have brought and combined their expertise in medicine and instrumental optics. Among other factors, the following quantities have been measured: illumination uniformity and its influence on recorded images, image resolution, light transmission of the illumination and imaging systems, depth of focus and image distortion. Those parameters have significant impact on image quality and eventually on the evaluation of a disease in a patient.

Key words: optical devices $\bullet$ optical imaging • technical report

\section{Wstęp}

Badania diagnostyczne oraz zabiegi lecznicze w otorynolaryngologii wykonywane są coraz częściej przy wykorzystaniu endoskopów optycznych. Dzięki nim lekarz przeprowadzający badania czy też operacje jest w stanie zobrazować niewidoczne z zewnątrz struktury anatomiczne, a także wykonać coraz doskonalsze zabiegi małoinwazyjne i mikrochirurgiczne. Swoją popularność endoskopy zawdzięczają relatywnie niskiej inwazyjności, przy jednoczesnym zapewnieniu dobrej jakości powiększonego obrazu powierzchni obserwowanego narządu lub jego części [1-3]. Wysoka jakość tego odwzorowania zależy w dużej mierze od jakości układów optycznych, będących najważniejszym składnikiem endoskopów i fiberoskopów [4]. Jakość ta zależy zarówno od konstrukcji, jak i od jakości wykonania oraz montażu układów optycznych. Większość producentów podaje w katalogach jedynie wybrane parametry optyczne, takie jak: długość części roboczej, średnicę zewnętrzną, kąt obserwacji oraz ewentualnie optymalny dystans roboczy pomiędzy końcem endoskopu a badanym obiektem. Ograniczenie się do tych parametrów nie pozwala użytkownikom na prawidłową ocenę i optymalny wybór oferowanego sprzętu. Ponadto użytkownik nie ma możliwości dokonania oceny, sprawdzenia, czy podawane w ulotce informacyjnej parametry są zgodne z rzeczywistością. Problem zaczyna się już po zakupie, gdy obraz uzyskany $\mathrm{z}$ endoskopu jest ciemny, mało kontrastowy. Wychodząc naprzeciw zapotrzebowaniu środowiska medycznego, w Instytucie Optyki Stosowanej oraz Instytucie Fizjologii i Patologii Słuchu opracowane zostały specjalistyczne procedury badania parametrów 


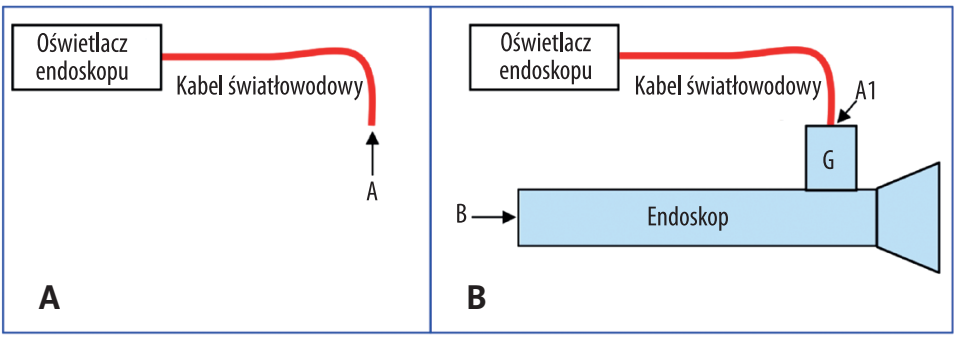

Rycina 1. Schemat układu do pomiaru współczynnika transmisji światła przez optyczny układ oświetlający endoskopu

Figure 1. Set-up for the measurement of the transmission coefficient of the endoscopic optical illumination system

optycznych endoskopów. Zaproponowane procedury dotyczą pomiarów zarówno układu oświetlającego badany obiekt, jak i układu rejestrującego obraz i umożliwiają dokonanie właściwej oceny jakości układu optycznego wziernika. Badania te pozwalają na obiektywną ocenę i porównanie parametrów komercyjnie oferowanych endoskopów oraz mogą ułatwić lekarzom wybór sprzętu o najlepszych parametrach użytkowych $[5,6]$.

\section{Procedury pomiarowe}

Parametry optyczne wzierników związane są z ich budową (zależną od planowanego zastosowania - wzierniki uszne, zatokowe itp.), dlatego też endoskopy podzielone zostały do badań na pakiety, w zależności od ich długości, średnicy, kąta skierowania itp., w ramach których były porównywane. Parametry optyczne endoskopów zależą od ich konstrukcji optycznej i mechanicznej, jakości wykonania poszczególnych elementów oraz jakości ich montażu zarówno w części oświetlającej obiekt, jak i rejestrującej obraz. Do wyznaczenia wartości wybranych parametrów optycznych zostało opracowane i zbudowane w INOS zintegrowane laboratoryjne stanowisko pomiarowe, umożliwiające obiektywne porównanie parametrów optycznych endoskopów oraz określenie wad układu pomiarowego mających wpływ na ocenę stanu obserwowanych tkanek dokonywaną przez lekarza w trakcie badań medycznych.

Stanowisko pomiarowe oprócz systemów montażowych oraz pozycjonujących endoskop w trakcie pomiaru składało się z:

- oświetlacza halogenowego wraz z kablem światłowodowym dostosowanym konstrukcyjnie do gniazda wejściowego endoskopu,

- miernika natężenia światła LabMaster Ultima z fotodetektorem LM-2,

- kamery CCD DMK 31BF03 firmy The Imaging Source Europe GmbH o matrycy fotodetektorów $1024 \times 768$ pikseli i wymiarach piksela 4,65×4,65 $\mu \mathrm{m}$,

- optycznego układu sprzęgającego „ZOOM” łączącego wziernik z kamerą,

- zestawu płytek testowych i kalibracyjnych.

Obsługa stanowiska pomiarowego oraz analiza uzyskanych wyników odbywała się za pomoca oprogramowania komputerowego opracowanego w INOS. Stanowisko zostało zbudowane na specjalnym stole optycznym, zapewniającym dużą stabilność (mechaniczną i termiczną) w trakcie wykonywania pomiarów. Mierzono następujące parametry optyczne endoskopów:

- współczynnik transmisji światła przez optyczny układ oświetlający wziernika,
- współczynnik transmisji światła przez optyczny układ obrazowy wziernika,

- jednorodność oświetlenia obiektu przez układ oświetlający wziernika, rejestrowaną za pomocą układu obrazowego wziernika,

- rozdzielczość optycznego układu obrazowego wziernika,

- głębię ostrości optycznego układu obrazowego wziernika.

- współczynnik opisujący deformację obrazu przez optyczny układ obrazowy wziernika.

\section{Pomiar współczynnika transmisji światła przez optyczny układ oświetlający endoskopu}

Schemat układu pomiarowego przedstawiony jest na rycinie 1 .

Rycina 1A przedstawia schemat układu do pomiaru światła wychodzącego z oświetlacza wziernika na wyjściu kabla światłowodowego (A), wprowadzanego następnie na wejście (A1) układu oświetlającego wziernika poprzez gniazdo G. Rycina 1B przedstawia schemat układu do pomiaru transmisji układu oświetlającego wziernika.

Pomiar współczynnika transmisji układu oświetlającego endoskopu polegał na wyznaczeniu stosunku natężeń światła mierzonych w punktach (A) i B.

W przypadku wzierników przeznaczonych do obserwacji obiektów (tkanek i narządów) pod kątem, powierzchnia fotodetektora była prostopadła do osi optycznej wziernika podanej przez producenta (równoległa do płaszczyzny wejściowej wziernika). Identyczny warunek, co do ustawienia endoskopu względem: detektorów, oświetlaczy oraz płytek testowych i kalibracyjnych, został przyjęty również przy wyznaczaniu wszystkich parametrów optycznych.

\section{Pomiar współczynnika transmisji światła przez optyczny układ obrazowy wziernika}

Schemat układu pomiarowego do pomiaru współczynnika transmisji układu optycznego endoskopu przedstawiony jest na rycinie 2 .

W odległości L od końcówki kabla światłowodowego oświetlacza endoskopu umieszczona została matówka z przesłoną otworkową (C1) o średnicy otworu porównywalnej ze średnicą wejściową układu optycznego endoskopu. Dokonywano pomiaru natężenia światła wychodzącego z przesłony otworkowej (C1) (rycina 1A), a następnie dostawiano endoskop (rycina 1B) i dokonywano pomiaru natężenia światła na wyjściu układu obrazowego endoskopu (C2). Współczynnik transmisji układu obrazowego endoskopu określany był stosunkiem tych dwóch natężeń. 


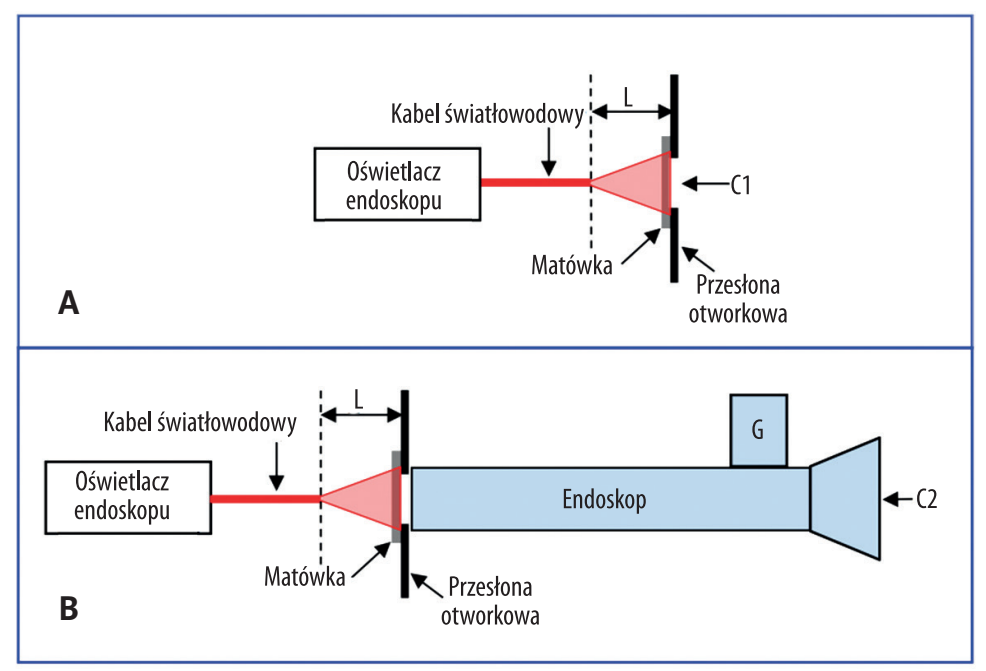

Rycina 2. Schemat układu do pomiaru współczynnika transmisji światła przez optyczny układ obrazowy wziernika

Figure 2. Set-up for the measurement of the endoscope imaging optical system transmission coefficient

Wartości transmisji układu oświetlającego oraz układu rejestrującego obraz porównywane były dla endoskopów $\mathrm{z}$ danego pakietu. Oferowane komercyjnie endoskopy różnią się zarówno konstrukcją układu optycznego, jak i jakością wykonania elementów optycznych. Endoskopowy optyczny układ oświetlający w większości modeli jest układem światłowodowym. Na jego jakość wpływają zarówno parametry zastosowanych światłowodów (tłumienność), jak i sposób rozprowadzenia światłowodów z gniazda wejściowego endoskopu (G) do czoła oświetlacza oraz powierzchnia czynna światłowodów (w praktyce odpowiadająca ich liczbie). Na zwiększenie transmisji światła w układzie obrazowym endoskopu ma wpływ jakość warstwy antyrefleksyjnej naniesionej na elementy optyczne.

Parametr transmisji światła przez układ obrazowy endoskopu jest jednym $\mathrm{z}$ istotnych parametrów określających, czy dany endoskop jest „jasny” czy „ciemny”. Oczywiście w przypadku „ciemnych” endoskopów, charakteryzujących się niską wartością współczynnika transmisji światła, możliwe jest zwiększenie mocy oświetlacza - to jednak może powodować nadmierne nagrzewanie się endoskopów, skutkujące zmatowieniem powierzchni soczewek układu obrazowego czy utratą właściwości klejów użytych do montażu, a w efekcie pogorszeniem jakości obserwowanego obrazu oraz możliwością ich rozszczelnienia (rozhermetyzowania), a tym samym znacznym skróceniem czasu ich użytkowania.

\section{Pomiar jednorodności oświetlenia obiektu przez układ oświetlający wziernika, rejestrowanej za pomocą układu obrazowego wziernika}

Jakość układów oświetlającego oraz obrazowego endoskopu opisywana jest również przez kolejny badany parametr, jakim jest jednorodność oświetlenia obiektu. Schemat układu pomiarowego przedstawiony jest na rycinie 3 .

W odległości roboczej (L) od czoła (C) endoskopu ustawiony był rozpraszający biały ekran, na który padało światło generowane przez układ oświetlający endoskopu. Obszar pomiarowy był kołem, którego średnica została ustalona indywidualnie dla każdego z pakietów endoskopów na podstawie danych producenta oraz doświadczenia lekarzy z IFPS. W celu zachowania powtarzalności pomiarów i możliwości porównywania parametrów endoskopów w danym pakiecie, powiększenie optycznego układu sprzęgającego „ZOOM” było ustawiane tak, aby długość średnicy rejestrowanego obrazu obszaru pomiarowego była równa długości krótszego boku matrycy fotodetektorów kamery (obraz tego obszaru był kołem wpisanym w pole widzenia kamery). Oświetlany obszar był większy niż obszar podlegajacy analizie i wynikał $\mathrm{z}$ parametrów (kąta świecenia) oświetlacza wziernika. Rejestrowany był obraz białego ekranu. Jasność obrazu była ustawiana tak, aby maksymalna rejestrowana przez piksele kamery wartość intensywności światła była zbliżona do wartości wysycenia fotodetektorów. Wartość ta była monitorowana „on-line” w trakcie ustawiania parametrów oświetlenia i kamery. Zapobiegało to, naturalnej w trakcie obserwacji wzrokowej, opcji przesycenia pikseli w poszczególnych partiach obrazu w kamerze, podczas „rozjaśniania” ciemnych, słabiej widocznych fragmentów oglądanego obiektu.

Do opisu jednorodności oświetlenia obszaru pomiarowego stosowano 3 parametry. W celu wyznaczenia pierwszego z nich obszar pomiarowy zarejestrowanego obrazu został podzielony na 16 wycinków koła o równej powierzchni (rycina 3b). Suma intensywności światła rejestrowanego przez wszystkie piksele kamery znajdujące się wewnątrz wycinka koła o nr j jest oznaczona jako $\mathrm{E}_{\mathrm{j}}$. Spośród wszystkich zmierzonych wartości $\mathrm{E}_{1} \div \mathrm{E}_{16}$ wybierane były dwie: o najmniejszej intensywności - oznaczonej jak $\mathrm{E}_{\text {min }}$ oraz największej intensywności - oznaczonej jako $\mathrm{E}_{\max }{ }^{\min }$. Parametrem był stosunek obydwu wartości: $\mathrm{E}_{\text {min }} / \mathrm{E}_{\text {max }}$. Wartości tego parametru w przypadku badanych endoskopów mieściły się w przedziale: $0,4-0,7$.

Im mniejsza wartość $\mathrm{E}_{\min } / \mathrm{E}_{\max }$, tym większa jest różnica $\mathrm{w}$ równomierności oświetlenia badanej powierzchni (zbyt jasne bądź zbyt ciemne fragmenty obrazu), co w praktyce może utrudniać prawidłową interpretację obrazów tkanek obserwowanych przez lekarza.

Dla lepszego opisu równomierności rozkładu intensywności światła w obrazie rejestrowanym przez endoskop wyznaczano dwa dodatkowe parametry. W tym celu w obszarze pomiarowym znajdowana była największa wartość 

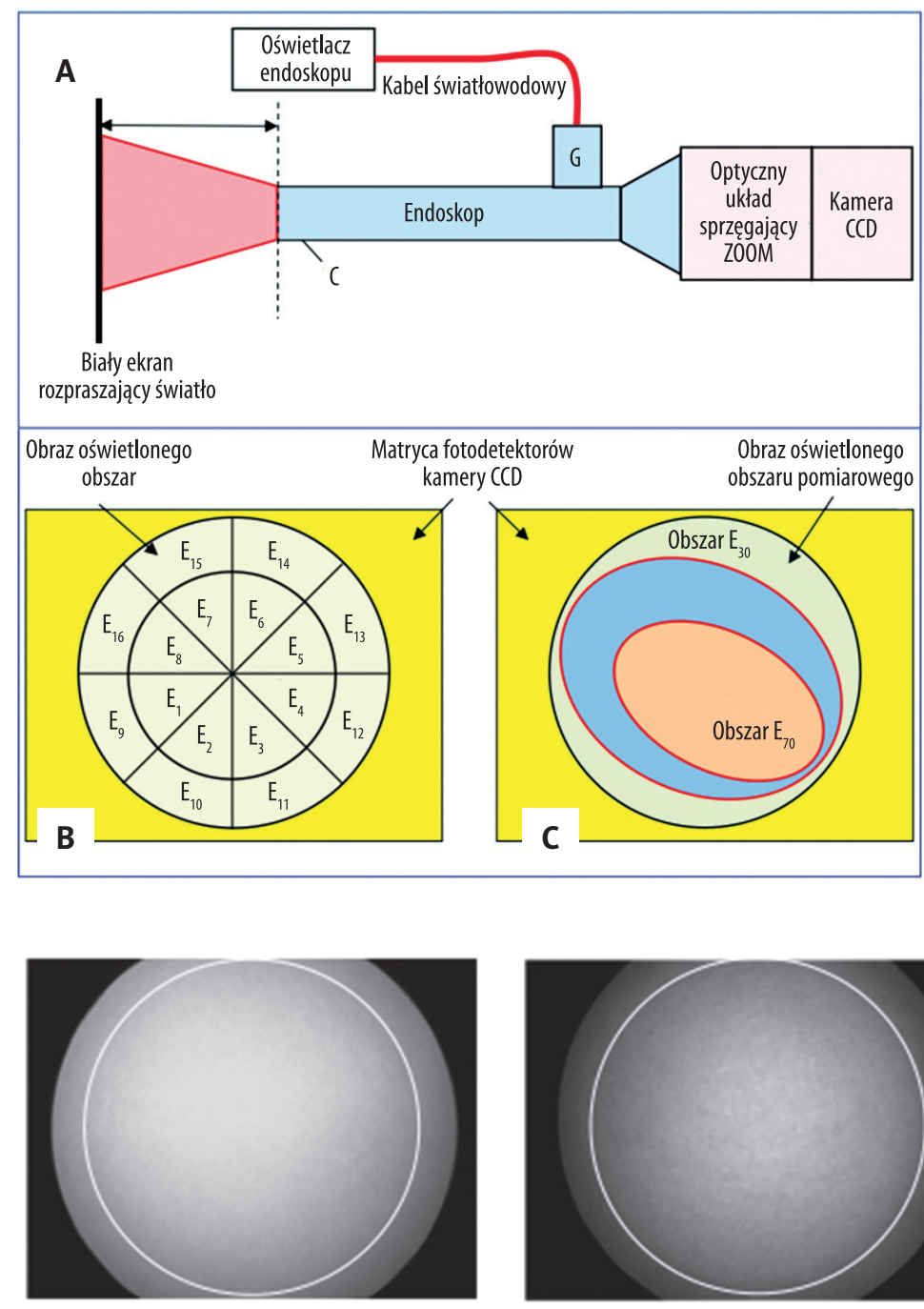

$\mathrm{E}_{\text {min }} / \mathrm{E}_{\max }=0,67$

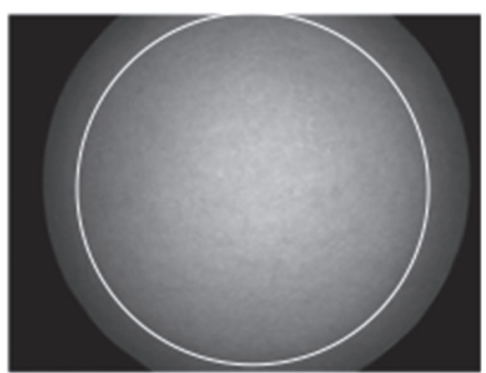

$\mathrm{E}_{\min } / \mathrm{E}_{\max }=0,55$
Rycina 3. Schemat układu do pomiaru jednorodności oświetlenia obiektu przez układ oświetlający wziernika

Figure 3. Set-up for the measurement of the illumination uniformity of the object in the endoscope illumination system

Rycina 4. Przykładowe obrazy oświetlonej powierzchni z zaznaczonym obszarem pomiarowym o zróżnicowanej intensywności oświetlenia

Figure 4. Exemplary surface images with highlighted regions of differentiated illumination intensity

intensywności światła zarejestrowana przez piksel kamery - $\mathrm{I}_{\mathrm{MAX}}$. Następnie sumowane były wartości intensywności światła zarejestrowane przez piksele kamery, które były większe bądź równe $70 \%$ maksymalnej wartości $\left(\mathrm{I}_{70}\right)$. Obszar przez nie zajmowany oznaczono jako $E_{70}$, a jego powierzchnię jako $S_{70}$. Analogicznie wyznaczona została suma wartości pikseli o intensywności mniejszej bądź równej 30\% maksymalnej wartości $\left(\mathrm{I}_{30}\right)$. Obszar przez nie zajmowany oznaczono jako $\mathrm{E}_{30}$, a jego powierzchnię jako $\mathrm{S}_{30}$. Parametrami, które były wykorzystane do porównywania jakości oferowanych endoskopów, były wartości $\mathrm{I}_{30} / \mathrm{I}_{70}$ oraz $\mathrm{S}_{30} / \mathrm{S}_{70}$. Im większa jest wartość tych dwóch ostatnich parametrów, tym gorsza jest jednorodność oświetlenia obiektu. Rycina 3b przedstawia schematycznie obszar zajmowany przez piksele o intensywności wyższej lub równej 30\% i 70\% maksymalnej wartości.

Przykładowe obrazy o zróżnicowanej intensywności oświetlenia pokazane są na rycinie 4 .
Rycina 5 przedstawia przykładowe obrazy o bardzo zróżnicowanej jednorodności oświetlenia dla dwóch egzemplarzy różnych endoskopów tej samej kategorii.

Rycina 5A przedstawia obraz powierzchni niejednorodnie oświetlony przez układ oświetleniowy endoskopu \#1, natomiast rycina 5B obraz z zaznaczonym obszarem o intensywności pikseli powyżej 70\% natężenia maksymalnego (biały), pomiędzy 30\% a 70\% natężenia maksymalnego (jasnoszary) oraz poniżej 30\% natężenia maksymalnego (ciemnoszary). Wyraźnie widoczna jest decentracja obrazu względem osi endoskopu. Czerwonym okręgiem zaznaczono obszar analizy. Analogicznie ryciny 5C i 5D przedstawiają obrazy zarejestrowane za pomocą endoskopu \#2. Równomierność oświetlenia jest w tym przypadku dużo lepsza.

Wyznaczone powyższe trzy parametry opisują w różny sposób równomierność oświetlenia tkanek obserwowanych za pośrednictwem endoskopów. Duża niejednorodność 

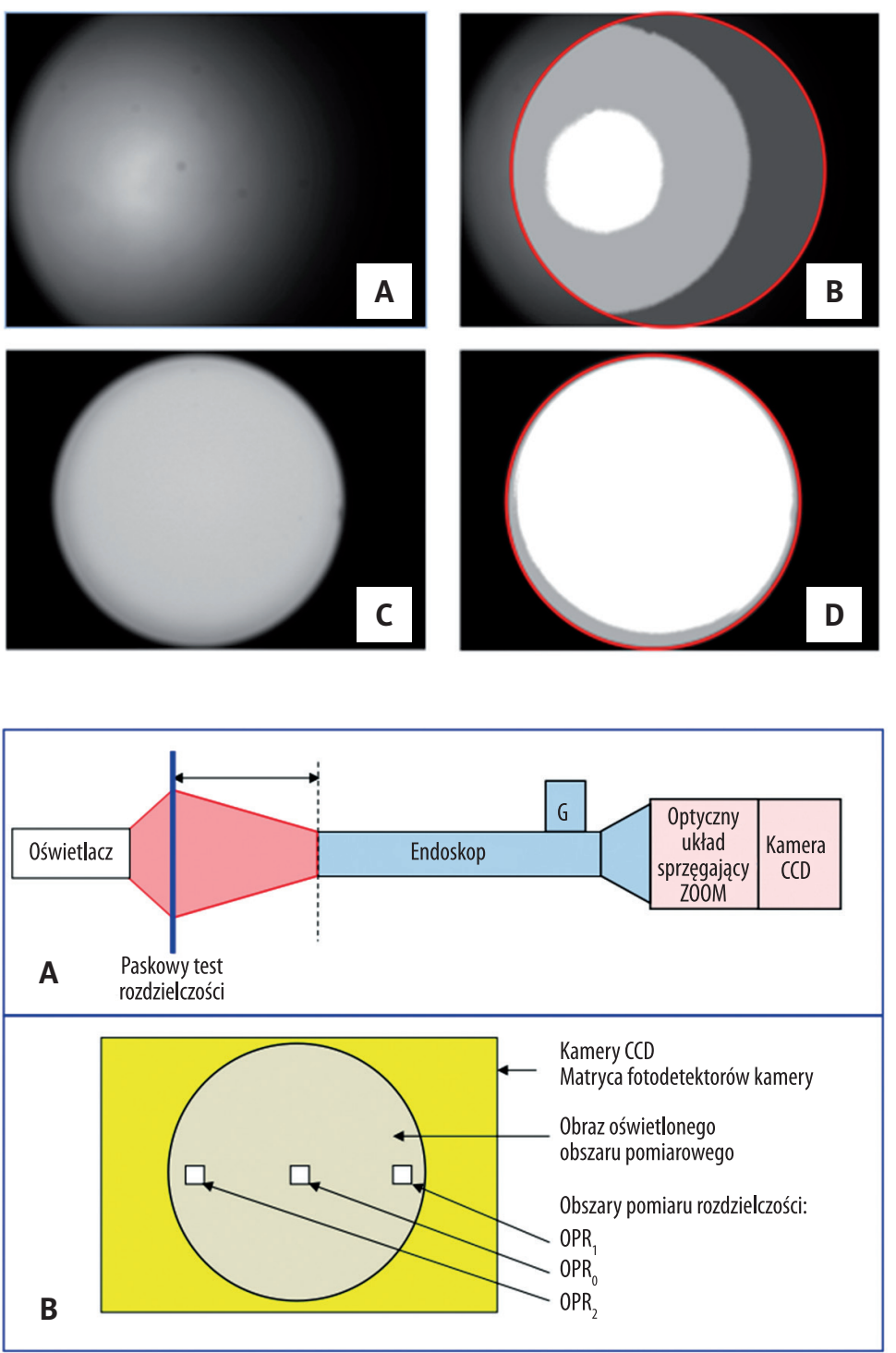

Rycina 5. Obrazy powierzchni oświetlonej przez układ oświetleniowy endoskopu

Figure 5. Surface images illuminated by the endoscope illumination system
Rycina 6. Schemat układu do pomiaru rozdzielczości optycznego układu obrazowego wziernika

Figure 6. Set-up for the measurement of the optical imaging endoscope system resolution oświetlenia może utrudniać prawidłową interpretację przez lekarza obserwowanych obrazów tkanek.

\section{Pomiar rozdzielczości optycznego układu obrazowego wziernika}

Kolejne parametry endoskopów opisują własności układu optycznego rejestrującego obraz. Parametry te zależą przede wszystkim od konstrukcji optycznego układu obrazującego endoskopu, jakości wykonania i montażu poszczególnych elementów optycznych.

Jednym z badanych parametrów była rozdzielczość optycznego układu obrazującego, czyli zdolność do rozróżniania szczegółów w obiekcie. Schemat układu pomiarowego przedstawiony jest na rycinie 6 .

Pomiary rozdzielczości dokonywane były za pomocą testu rozdzielczości 1951 USAF firmy Edmund Optics. Test składał się z szeregu struktur obrazowych (grup 3 linii) o różnym i standaryzowanym powiększeniu, charakteryzujących się różnymi gęstościami linii, zwanymi częstościami przestrzennymi, opisywanymi liczbą linii na $1 \mathrm{~mm}$. Umożliwiał on badanie rozdzielczości układów optycznych w przedziale od 1 do 50 linii/mm. Przykładowy test rozdzielczości przedstawiony jest na rycinie 7 .

Dla potrzeb oceny endoskopów zdefiniowano rozdzielczość układu optycznego w obszarze pomiarowym jako częstość przestrzenną, przy której kontrast linii jest nie gorszy niż 0,2 .

Test rozdzielczości oświetlany był w układzie pomiarowym za pomocą światła rozproszonego generowanego przez układ oświetlacza. Po ustawieniu ostrości obrazu w centralnej części pola widzenia endoskopu, rozdzielczość układu obrazującego mierzona była w środku obszaru pomiarowego w obszarze pomiaru rozdzielczości OPR. W tym celu wprowadzano do niego kolejne struktury testu i mierzono ich kontrast, poszukując najmniejszej (o największej gęstości linii), której kontrast będzie nie gorszy niż 0,2. Częstość przestrzenna tej struktury była uznawana za rozdzielczość układu optycznego w obszarze $\mathrm{OPR}_{0}$ i oznaczana jako $\mathrm{CP}_{0}$. 


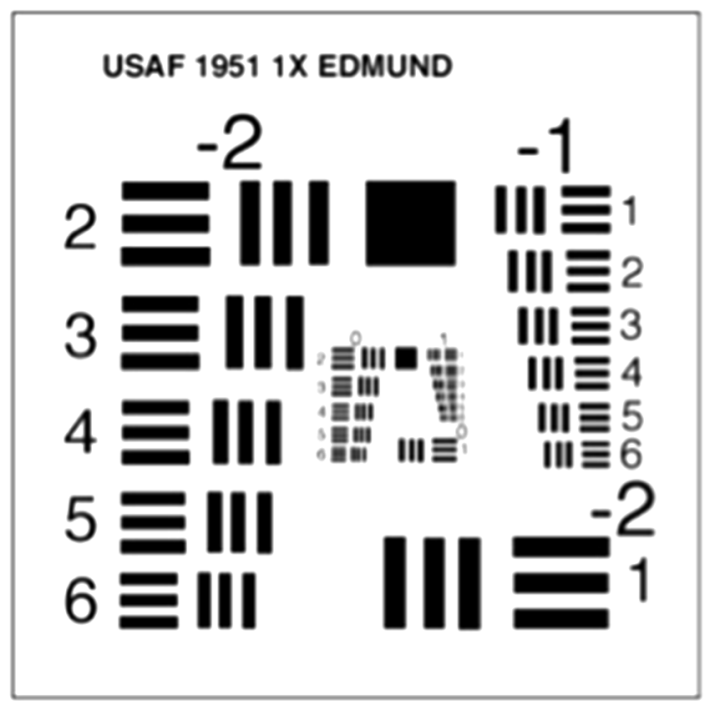

Rycina 7. Test rozdzielczości

Figure 7. Resolution test target

Następnie w analogiczny sposób, nie zmieniając ostrości zobrazowania, mierzono rozdzielczość układu w obszarach $\mathrm{OPR}_{1}$ i oznaczano jako $\mathrm{CP}_{1}$ oraz $\mathrm{OPR}_{2}$ i oznaczano jako $\mathrm{CP}_{2}$. Centra ww. obszarów pomiarowych leżały na poziomej średnicy pola widzenia $\mathrm{w}$ odległości $\pm 1 / 2 \mathrm{R}$ od środka pola widzenia endoskopu, gdzie R jest promieniem obszaru pomiarowego.

Wynikiem pomiarów były dwa parametry: pierwszy dotyczący rozdzielczości w centrum obszaru pomiarowego - $\mathrm{CP}_{0}$ i drugi - będący różnicą pomiędzy rozdzielczością w centrum i na bokach obszaru pomiarowego określoną wzorem $\left(\mathrm{CP}_{1}+\mathrm{CP}_{2}\right) /\left(2^{\star} \mathrm{CP}_{0}\right)$. Parametry te określają, jak małe szczegóły w obrazie (zmiany chorobowe) będzie w stanie wykryć lekarz na pojedynczym obrazie. Są to szczególnie ważne parametry w sytuacjach, kiedy lekarz (obserwator) ma bardzo ograniczoną możliwość przesuwu endoskopu w poprzek badanego obiektu w celu wizualizacji go centralną częścią endoskopu, mającą teoretycznie najlepsze parametry odwzorowania.

W literaturze istnieje wiele definicji i specjalistycznych pojęć związanych z kontrastem obrazu i jego oceną. Przyjęta przez autorów procedura związana jest jedynie $z$ porównywaniem endoskopów z danego pakietu.

\section{Pomiar głębi ostrości optycznego układu obrazowego wziernika}

Za pomocą układu pomiarowego przedstawionego na rycinie 6 przeprowadzony został również pomiar głębi ostrości układu obrazowego. W tym pomiarze ograniczono się jedynie do badania rozdzielczości w środkowej części obszaru pomiarowego $\left(\mathrm{STR}_{0}\right)$. W pierwszym etapie realizacji procedury związanej z badaniem głębi ostrości wyznaczana była rozdzielczość układu $\mathrm{CP}_{0}$. Następnie test rozdzielczości był przesuwany wzdłuż osi optycznej układu pomiarowego (bez regulacji ostrości obrazu), w trakcie którego wyznaczany był kontrast struktury prążkowej wybranej w pierwszym etapie. Przyjętym parametrem określającym głębię ostrości była odległość pomiędzy punktami na osi optycznej, dla których wartość kontrastu spadała o $50 \%$ w stosunku do kontrastu uzyskanego przy wyznaczaniu wartości $\mathrm{CP}_{0}$.

\section{Pomiar współczynnika opisującego deformację obrazu przez optyczny układ obrazowy wziernika}

Kolejnym istotnym parametrem opisującym jakość obrazowania układu optycznego jest dystorsja, odpowiedzialna za deformację rejestrowanego obrazu. Pojawia się ona wtedy, gdy powiększenie układu optycznego nie jest stałe dla całego pola widzenia, a zmienia się wraz z odległością od osi optycznej układu. Jej efektem są najczęściej „zaokrąglenia" obrazu linii prostych przedmiotu. Dla lekarzy oznacza to możliwość popełnienia błędu w ocenie kształtu i wymiaru obserwowanej tkanki, zwłaszcza że wartość dystorsji jest zmienna w przypadku używania obiektywów typu zoom. Schemat układu do pomiaru dystorsji pokazany jest na rycinie 8 .

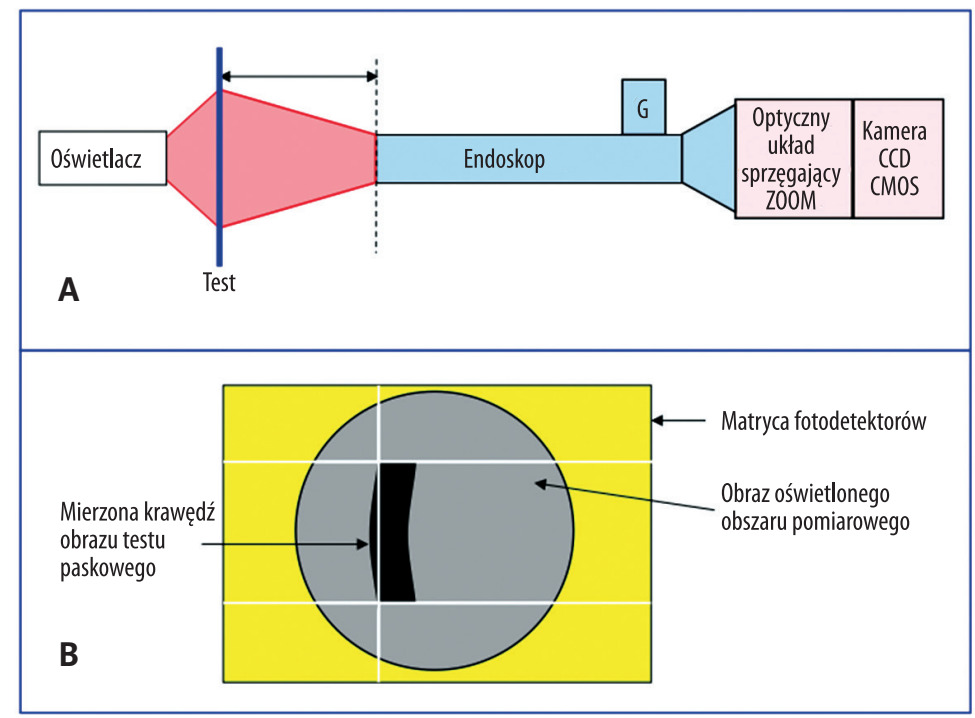

Rycina 8. Schemat układu do pomiaru dystorsji

Figure 8. Set-up for distortion measurements 

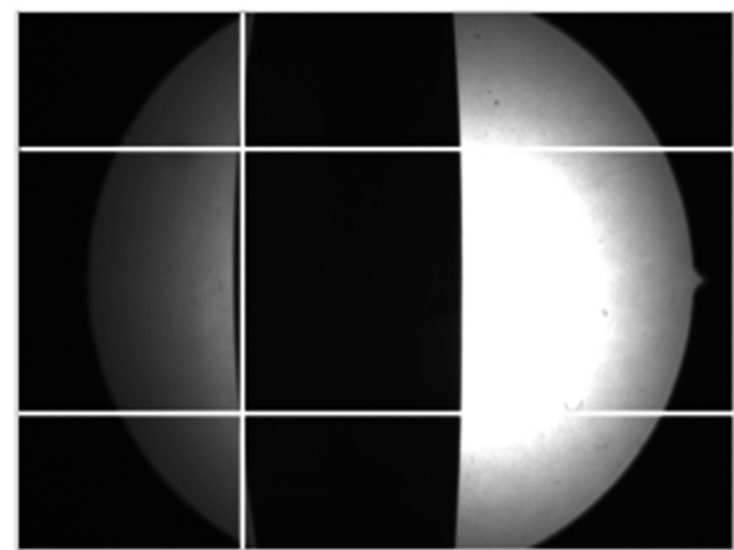

Rycina 9. Obraz testu paskowego zdeformowany przez dystorsję układu obrazującego endoskopu wraz z zaznaczonymi liniami do pozycjonowania testu w obszarze pomiarowym

Figure 9. Degraded image of a strip test target as a result of distortion in the endoscope imaging system with reference lines in the measurement field

Układ ten jest identyczny z układem do pomiaru rozdzielczości, z tym że w układzie do wyznaczenia wielkości dystorsji test rozdzielczości został zastąpiony testem paskowym zawierającym nieprzezroczyste paski o prostych i ostrych krawędziach. Krawędź struktury paskowej ustawiona była pionowo w polu widzenia kamery CCD, równolegle do krótszego boku matrycy CCD, w środku obszaru pomiarowego. Następnie test przesuwany był poziomo do pozycji, w której krawędź paska przechodzi przez punkty przecięcia dwóch linii poziomych z linią pionową. Każda $\mathrm{z}$ tych linii ustawiona była w odległości $1 \frac{1}{2} \mathrm{R}$ od środka obrazu, gdzie R jest promieniem obszaru pomiarowego. Położenie testu w miejscu pomiaru dystorsji pokazane jest na rycinie $8 \mathrm{~B}$. W procedurze pomiarowej mierzona była wartość H (wyrażona w pikselach obrazu), będąca maksymalną odległością punktów obrazu krawędzi paska od linii pionowej. Parametrem opisującym deformacje geometryczne obrazu była wielkość równa $H /\left(0,5^{\star} R\right)$. Przykładowy obraz zarejestrowany $\mathrm{w}$ trakcie procesu pomiaru dystorsji pokazano na rycinie 9. Dobrze widoczna jest deformacja krawędzi paska wywołana dystorsją układu optycznego endoskopu, która powoduje wykrzywienie linii krawędzi paska będących w teście liniami prostymi.

\section{Podsumowanie}

W pracy skoncentrowano się na opracowaniu procedur, które mogą zostać wykorzystane przy porównywaniu parametrów optycznych endoskopów, w tym stosowanych w zabiegach medycznych. Wynikiem przeprowadzonych badań wzierników były wyznaczone, w zaproponowanym optycznym układzie pomiarowym, zestawy wartości parametrów. Była to jedna z pierwszych w Polsce prób wprowadzenia nowych standardów dotyczących oceny jakości endoskopów optycznych. Jest to szczególnie istotne w sytuacji, kiedy producenci sprzętu medycznego nie podają parametrów, które odgrywają znaczącą rolę w procesie odwzorowywania obrazu. Częściowo wynika to właśnie z braku zatwierdzonych powszechnie procedur pomiarowych. Przedstawione w artykule badania wykonane zostały przez niezależny, państwowy instytut badawczy, przy wykorzystaniu procedur identycznych dla wszystkich dostawców. Pomiary te miały na celu przeprowadzenie obiektywnej oceny i porównania oferowanego, najczęściej w procedurze przetargowej, sprzętu medycznego. Specjalistyczne stanowisko pomiarowe umożliwia wprowadzenie dodatkowych kryteriów w dokumentach przetargowych, w których dotychczas głównym kryterium wyboru była cena. Zazwyczaj sprowadzało się to niestety do zakupu tańszego sprzętu, ale o znacznie gorszych parametrach wizyjnych, co zwłaszcza w medycynie ma niebagatelne znaczenie.

\section{Piśmiennictwo:}

1. Bartkowska-Śniatkowska A, Puklińska-Cieśla K, Ignyś I, Grześkowiak M, Rosada-Kurasińska J. Zabiegi endoskopowe u dzieci - komfort i bezpieczeństwo. Przegląd Gastroenterologiczny, 2008; 3(3): 165-68.

2. Skalski A, Zieliński T. Segmentacja i dopasowywanie cyfrowych obrazów medycznych: przetwarzanie nagrań wideo-endoskopowych strun głosowych oraz danych tomograficznych zmian rakowych. Pomiary, Automatyka, Kontrola, 2008; 54(6): 330-33.

3. El-Meselaty K, Bard-El-Dine MMK, Mandour M, Murad M, Darweesh R. Endoscope affects decision making in cholesteatoma surgery. Otolaryngol Head Neck Surg, 2003; 129(5): $490-96$.
4. Podbielska H, red. Optyka biomedycza. Wybrane zagadnienia. Wrocław: Oficyna Wydawnicza Politechniki Wrocławskiej; 2011.

5. Sakierski R. Zastosowanie neuronowych systemów ekspertowych do pozyskiwania wiedzy $\mathrm{z}$ medycznych baz danych obrazów endoskopowych. Prace Naukowe Akademii Ekonomicznej we Wrocławiu, 2002; 931: 245-57.

6. Wormald PJ. Endoskopowa chirurgia zatok. Anatomia, trójwymiarowa rekonstrukcja i technika chirurgiczna. Warszawa: Medisfera; 2015. 